DOI https://doi.org/10.15407/csc.2021.05-06.061

UDC 007:330.341

\author{
A.I. MOROzovA, Chief engineer-programmist, \\ International Research and Training Centre \\ for Information Technologies and Systems of the NAS and MES of Ukraine, \\ Glushkov ave., 40, Kyiv, 03187 , Ukraine, \\ dep190@irtc.org.ua \\ V.P. KOZLOVA, Research Associate, \\ International Research and Training Centre \\ for Information Technologies and Systems of the NAS and MES of Ukraine, \\ Glushkov ave., 40, Kyiv, 03187, Ukraine, \\ dep190@irtc.org.ua
}

\title{
INFORMATION ARCHITECTURE OF A MODERN ENTERPRISE IN THE PERIOD OF GENERAL DIGITALIZATION OF THE ECONOMY
}

\begin{abstract}
In modern conditions of digitalization of economy the information acquires the same value for activity of the enterprise, as well as finances, marketing, potential, production. This means that information is being transformed into a certain type of production resources and integrated with the business strategy. The approach to organizing a large amount of information at the enterprise is presented and the importance of developing and building a high-quality architecture of enterprise information for its successful operation is emphasized.
\end{abstract}

Keywords: enterprise architecture, architecture of information of the enterprise, structured information, unstructured information.

\section{Introduction}

Modern enterprise acts as a digital one, when it uses information technologies in all areas of its activities, namely: production, business processes, marketing and customer relationships. Thus, the production complex is being transformed into an enterprise with "digital thinking" while passing the path of digital transformation [1].

The modern view of information technologies (IT) for the enterprise shows that IT are designed to ensure high efficiency of enterprise management, optimize the collection and accumulation of information, reduce decision-making time through better and faster access to data and processing results.
According to Gartner analysts, IT are beginning to play not only the role of "technological substrate" that automates the business processes of the enterprise, but also become an element of its strategy necessary for the transition of the enterprise to a brand new level of operation. Information and IT components are becoming an integral part of a growing number of products and services [2].

One of the main problems of enterprises is the lack of correct information about the existing IT support of the business and the strategy of its further development. There is a paradoxical situation IT increase the efficiency of enterprise management, but their development is chaotic. We need a 
tool that ensures the relationship of strategic goals and objectives of the enterprise, business processes and technologies that support them. The development of enterprise architecture is required and as an integral part of it - the development of the architecture of information of the enterprise.

The purpose of this work is to present an approach to the organization of various information in the enterprise and emphasize the importance of developing and building a quality architecture of enterprise information for its competitiveness in the industrial market.

In the period of digitalization of the economy, the modern enterprise must meet the requirements of coexistence with other structures in the industrial market, in this regard, information technology and information should become part of the strategy of the enterprise. The advantages of this work are that it is proposed to consider all the various information about the current state of operating assets in a situation of turbulence of the production process at the enterprise as a single unit integrated into the system - the architecture of information of the enterprise.

\section{Enterprise Architecture}

Before starting to describe the architecture of information of the enterprise, it is necessary to get an idea of the architecture of the enterprise. This is important because enterprise management is the management of its architecture [3].

The definition of enterprise architecture is considered in two components - the enterprise and architecture.

Open Group (TOGAF methodology) defines "enterprise" as follows:

"Enterprise" is any set of organizations that has a common set of goals and/or a single result (end result). In this sense, an enterprise can be a government agency, an entire corporation, a division of a corporation, a separate department or a chain of geographically remote organizations associated with common property.

Gartner defines "architecture" as follows:

1. The main design or general concept used in creating the system, for example, in the architecture of the city or information system for customers; also "system abstraction or design, its structure, components and how they are interconnected".

2. A family of guidelines (concepts, policies, principles, rules, templates, interfaces, and standards) that should be used to create new IT capabilities.

Enterprise Architecture is designed to ensure alignment between the business and IT strategies, operating model, guiding principles, and the software development projects and service delivery. By taking a global, enterprise-wide, perspective across all the business services, business processes, information, applications and technology, Enterprise Architecture ensures the enterprise goals and objectives are addressed in a holistic way across all the application development projects and their deployment into production [4].

The concept of enterprise architecture includes such aspects as business architecture, the architecture of information, application systems architecture, technological architecture. Enterprise architecture is a means of combining and synchronizing the functional and business needs of the enterprise with the capabilities of information technology in terms of increasing complexity.

This concept is reflected in the concept of "Real-time enterprise", which defines the style of doing business, when relevant at any time information about business-critical processes is used to gain a competitive advantage by constantly reducing management delays [5].

The concept of real-time enterprise is based on the integration of everything related to the activities of the enterprise: infrastructure, systems, information, processes, personnel. In addition, the basis of this is the architecture of information technologies, and in a broader sense, the architecture of the enterprise as a whole.

Gartner defines the information technology architecture as follows:

IT architecture is a set of principles, guidelines or rules used by an enterprise to manage the acquisition, construction, modification and interaction of IT resources throughout the enterprise. These resources may include hardware, software, communications, development meth- 
odologies, modeling tools, and organizational structures [5].

Enterprise architecture is one of the tools of organizational changes. There are two main approaches to changes. The first is related to reorganization, process reengineering, and the second is related to knowledge management. Enterprise architecture is primarily knowledge management, i.e. the process of collecting and disseminating information about how the enterprise uses and should use information technologies in its activities.

The architecture of the enterprise includes the following architectural components:

- Information technology architecture is the main mechanism for achieving the goals of the enterprise through adequate IT infrastructure and systems. This is achieved through the creation of a number of interconnected architectural representations, which divide the architecture of the enterprise into different numbers of models related to such areas as business, information, application systems, technological infrastructure [6].

- Business model architecture describes enterprise strategy, management structures, requirements, constraints, and rules, as well as key business processes, their relationships, and interdependencies. Business architecture describes at the enterprise level how the main functions of the enterprise are implemented, including organizational and functional structures, roles and responsibilities.

- The architecture of application systems describes those systems that provide the necessary functionality to implement the logic of business processes of the enterprise.

- The technology architecture contains a description of the IT servers required to implement other architectures.

- The architecture of information identifies key assets related to structured and unstructured information that a business needs, including location, time, file types, databases, and other information repositories.

- The architecture of the enterprise is completed by physical models determined by technologies, hardware and software platforms selected for the implementation of information technology servers. The architecture of the enterprise does not make sense if it does not bring real benefits in the shortest possible time (within a clearly defined timeframe). One of the main tasks of enterprise architecture is the convergence of business units of the enterprise for effective work to achieve the goal (Fig. 1).

The concept of enterprise architecture is the upper level of modern development of ideas about the organizational processes of the enterprise, the point of merging approaches to organizational changes and changes in views on the role and use of information technology [7].

\section{The Architecture of Information}

Defining the architecture of information of the enterprise. The enterprise must look for effective means of working with information that comes from different sources and must be available at the right time and in the right place.

The architecture of information includes visions, principles, models and standards that provide the processes of creating, using and maintaining information related to the enterprise's activities.

Richard Saul Wurman believes that the architecture of information is a scheme of information organization. The effectiveness of this architecture is measured by the speed of information and the quality of the information found [8].

The architecture of information describes how information technologies provide the enterprise with opportunities for rapid decision-making, dissemination of information within the enterprise, as well as outside it - to business partners.

The architecture of information is a "mirror image" of business architecture. Yes, business architecture answers the question: "Given our shared vision of goals and strategies, who and what will do?"

The architecture of information answers the question "What information should be provided in order for these processes to be able to be performed by those who should perform them".

Peter Morvile and Louis Rosenfeld in their classic work on Information Architecture provide the following definitions of the architecture of information: 


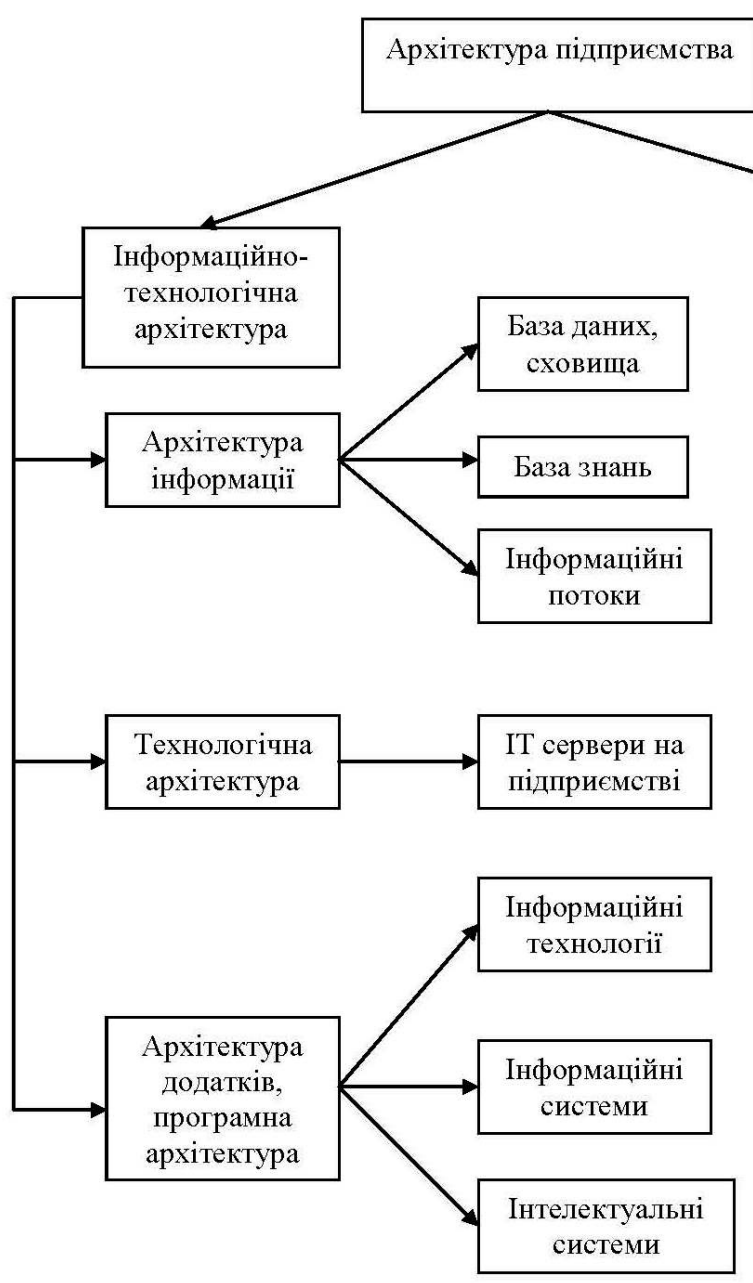

- Combination of schemes of organization, objectification and navigation, implemented in the information system;

- Structural design of the information space, which facilitates the implementation of tasks and intuitive access to content [9].

In general, the architecture of information is understood as the process of organizing and presenting relevant information to users in an intuitive form, using cataloging, navigation and user interface. This aspect of enterprise architecture emphasizes the positioning of information stored and processed as a strategic corporate resource and an integral part of the intellectual capital of the enterprise.

The essence and specifics of the architecture of information of the enterprise. The architecture of
Fig. 1. Elements of enterprise architecture information includes models that describe the processes of information processing, objects related to business events, information flows, the principles of formation and management of information. The architecture should describe both the data required to execute the processes - operational and analytical data and content.

The architecture of information also contains tools for assessing the quality of data, the frequency of their submission on demand, accounting for val$u e$ as an intangible asset.

Data in the enterprise goes through a large number of steps in the process of its life cycle. In such a stream, branches and mergers can occur and the same data can be processed by different application systems and stored in different databases (for ex- 
ample, customer data). This leads to data fragmentation, work with them of different departments and requires coordination within a single architecture of information of the enterprise.

Speaking about the architecture of information of the enterprise, it should be noted that the connecting links of its constituent elements are information flows, which, in turn, are considered the object of information logistics of the enterprise. The main task of information logistics is to deliver information to the enterprise management system and from it. One of the most important goals of information logistics is the effective management of these flows throughout the information network.

Proper organization of information flows, collection and analysis of relevant information plays an important role in the implementation of strategic plans of the enterprise. At this stage, decisions to adjust the strategy are important, the success of which depends on the timeliness and quality of the information on the basis of which they are made.

In terms of determining the efficiency of distribution of information flows there is a concept of information capacity of the enterprise. In studies related to the architecture of information of the enterprise, information capacity is proposed to be used to determine quantitative indicators of information potential (information resources, technologies and systems) of the enterprise.

The information capacity of the enterprise is the amount of information that is formed in the process of information activity of the enterprise [10].

The power of information flow is a new concept in the terminology of information technology. Its essence is that it characterizes the intensity of information processes passing over time and will determine the effectiveness of this flow.

Properly designed the architecture of information can allow the enterprise to achieve immediate improvements and at the same time build the infrastructure to further address emerging challenges.

The implementation of the architecture of information provides a single enterprise-wide access to certain data elements, timely access to accurate data and the appropriate level of security and protection for all data. This is the basis for the imple- mentation of decision support systems, transaction processing systems and analytical systems.

To understand the architecture of information and how data is stored and updated, it is important to distinguish between the types of application systems that provide access to data:

- online transaction processing systems (OLTP);

- online analytical processing (OLAP) systems;

- unstructured information (content) management systems.

The final set of disciplines related to the architecture of information is determined by the needs of production.

The field of the architecture of information has an intersection with other domains of enterprise architecture. A typical example of such a crosssection is the XML standard, which applies to both the architecture of information and application architecture.

\section{Development of the Architecture of Information of the Enterprise}

When developing (creating) the architecture of information, it is important to keep in mind that the architecture of information includes various areas and related instructions, such as:

- metadata;

- data modeling;

- database management systems;

- intermediate layer software for data access;

- data access mechanism;

- data security.

However, the final set of areas is determined by the needs of the enterprise.

The recommended first steps towards creating the architecture of information are the following:

- creation of a data dictionary and metadata repository;

- selection of a system for recording information about each data element.

These steps will further facilitate the creation of an online data warehouse that provides standard processes for retrieving, transforming, and loading data, as well as clearing data and creating metadata. The online repository is the foundation for the 
repeated multiple reuse of data, and later - for the creation of data warehouses and Data Marts.

After these first tasks are solved, it is necessary to provide such conditions that all processes of creation and access to the information at the enterprise correspond to the developed architecture.

The results of the process of developing the architecture of information are [11]:

- documented description of existing data sources; data models. Gartner experts do not recommend spending too much effort to create a single, complete and detailed model throughout the enterprise, as the cost of its development and subsequent support may be inadequate to the benefits. The main focus should be on identifying the semantic difference in the description of data coming from different sources, and the creation of relatively stable "canonical" representations of data describing their use by business users;

- a description of existing and planned information flows, relevant interfaces, data conversion or consolidation algorithms, as well as the necessary agreements at the level of the service related to data transfer;

- description of solutions for the organization of data storage - from shared directories to Data Marts and data warehouses;

- technologies and tools used for data conversion and management (Fig. 2).

When creating the architecture of information of the enterprise, different models of information are used. The purpose of developing information models is to create graphical representations of the needs of the enterprise and individual business processes in information. This becomes the basis for reorganizing business processes and designing new application systems, describing the interactions and information exchange that takes place between the enterprise and customers, the enterprise and partners.

For the architectural process, it is natural to consider information models at different levels of abstraction. For example, the view of such an information object as a "customer" for a high-level manager differs from $a$ more detailed view of the sales manager or marketer, who think in terms of more detailed segmentation of customers. In addition, the developer of the architecture of in- formation system will represent this object in the form of some entity with accurately defined set of attributes.

This top-down decomposition process is key to creating the architecture of information.

According to [11], an architectural process is a certain sequence of actions aimed at creating an architecture or architectural description. There are different levels of the architectural process $[5,11]$, namely:

I. Conceptual level. The conceptual level defines the components of the system and their purpose, usually informally. At this level, there are enough high-level models that describe the information flows between the functional units of the enterprise in the most general form. These flows are not associated with any particular application system and do not specify methods of access or physical storage of information, i.e. are considered at the business level without describing the problems of practical implementation.

This view is often used to discuss with management, business managers, end users the functional characteristics of the system (what it should do in terms of the end user).

II. Logical level. On a logical level, see, first for everything, the interaction of the components of the system, the interfaces and the protocols.

At this level, information and data model descriptions describe information requirements in a form and terms that are understandable to business users. The process of modeling at the logical level provides means of identifying, analyzing, defining, standardizing and normalizing the relationships between business processes and application systems, identifying information flows and relevant data elements that the enterprise needs.

Processes, information flows and data elements are logical facts that the enterprise must support for business operations.

This level of analysis allows you to identify common data elements that are used by various organizational units and various business processes, which reduces crossings and conflicts between these elements. However, it does not depend on the means of storing information in databases. 


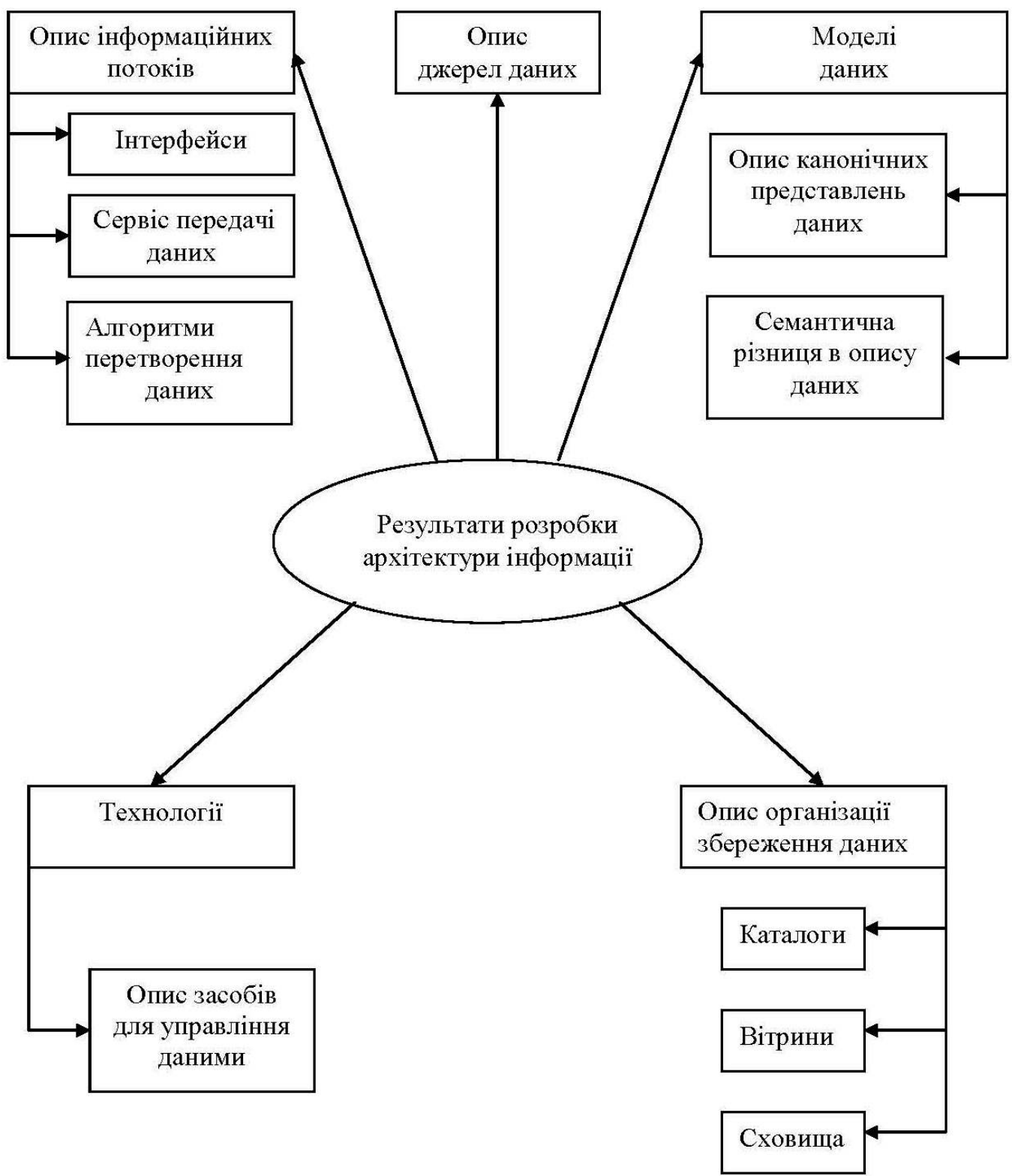

Fig. 2.The results of the development of enterprise information architecture

In this case, the model is used to collect and analyze data requirements and includes elements such as the entities, attributes, relationships and the number of entries.

- The entities are such objects as "Client", "Order", "Place", "Object" and others. The set of entities of the same type becomes a table in the database, and a row of this table is one realization of some entity.
- The attribute is a characteristic that provides more detailed information about the entity (object), for example, "Surname", "Name", "Gender". The attribute becomes a column in the data table. Key attribute is a unique entity identifier (for example, a serial number).

- Relationships show as one entity correlates with another. When describing the links are verbs, since there are actions. For example, a "citizen 
possesses real estate." The entity "citizen" "owns" some other entity "real estate".

- The number of entries shows how many entities can be in a relationship with another entity. For example, a citizen can own several real estate objects.

One of the means of data modeling in the logical level is the construction of models of "Entity - Relationship".

III. Physical level. Physical level describes an attachment to specific nodes of the location, types of equipment, environment characteristics (operating systems, etc.).

At the physical level, accurate answers are provided to such questions as "What data are needed to implement the logic of the business process by the relevant application system?", "How much different information objects (entities) are needed?", "What is the set of each entity data elements?".

The physical model of data is representative of how the data presented in the logical model will be stored in the database management system.

Metadata. An important concept relating to the architecture of information of the enterprise is the management of metadata (Metadata is data that describes other data).

Under the metadata management is understood the data management process associated with information assets of the organization to ensure integration, access, sharing, analysis, etc. Metadata management is an important process to achieve the best output of the enterprise.

Metadata management elements.

- Metadata repositories - used for storage, documenting, analysis and metadata management. It contain all data during all stages of the project life cycle: development, testing, commissioning.

- Business Glossary (Business Dictionary) Used to manage business terms together with appropriate definitions and relations between these terms.

- Data Lineage (the origin of data) - determines the origin of the data, the stages of transformation and data change, the direction of their movement.

- Impact analysis (analysis of influence) ensuring high information relative to the depen- dencies between data with further influence on target indicators.

- Rules Management - Automation of compliance with business rules that are tied to the elements of these and related metadata.

- Semantic Frameworks - support fortaxonomy, ER-models, ontologies, modeling languages such as RDF, OWL and UML.

- Metadata Ingestion and Translation (capture and transfer of metadata) - technologies and connectors for different data sources: RDBMS, BI, DIS, XML, etc. [12].

This provides management and access to data and metadata regardless of their internal logical structure and physical limits of their location, in order to organize the interaction of systems and various units within the enterprise and external organizations.

The idea is to use a common metamodel. A metamodel in computer science is a model that describes another model; transitive relationship between two models (for example: if the model M1 describes the language L0, in which the model M0 is formulated, then M1 is a metamodel M0; if the model M2 describes the language L1, in which the model M1 was formulated, then M2 is a metamodel M1, and M2 is then for M0 a metametamodel) [13].

The use of a common metamodel will manage the relationships between different data models and thus make them transparent at the corporate level.

Getting information about metadata is half the problem. The second half is related to determining the relationship between the metadata of one system with similar metadata of another.

The essence of metadata consists in the same definition at some level of abstraction of common data elements for different information systems of the enterprise. In this case, the data (for example, about the client) can be described differently in each system. However, there are common virtual models that unite them. If this is achieved, it is easier to implement data exchange between systems.

Virtual models for different users can be represented in different ways: databases, business objects, selection from the database, enterprise data 
models, documents. Importantly, object definitions are created using models.

The Meta-Object Facility (MOF) standard helps define the required metadata models.

When developing the architecture of information, it is necessary to take into account that the enterprise uses both structured and unstructured information. Decision-makers rely only one-third on information from structured sources (documents and reports generated by computer systems). Two thirds of the sources of importance in terms of decision-making - is information obtained from meetings, telephone conversations, participation in conferences, etc.

In this case, different forms of information require specific technologies and methods of working with it:

- structured information - relational and object models;

- semi-structured information - evolving standards based on XML;

- unstructured information in the form of texts, graphs, images - accompanied by certain descriptive data (metadata and catalogs).

Part of the process of describing the architecture of information is the collection of information that defines objects "as is", the definition of the target state, as well as the plan for the transition from the current state to the target.

Typically, the current state of the architecture of information is described using logical and physical data models - these models are usually platformdependent.

The target state is described in the form of platform-independent semantic or virtual models.

At the moment there is no universal means which would allow to solve the problems connected with construction of the architecture of information of the enterprise. However, modeling tools based on the use of UML, as well as the dissemination of XML and other standards based on it, are promising.

\section{Summary}

The approach to structuring of various forms of information used at the enterprise in difficult conditions of production process in the period of digitalization of economy - in the form of development and construction of the architecture of information of the enterprise is presented.

Properly and qualitatively designed and built the architecture of information of the enterprise will allow the company's management to reduce the time of decision-making by quickly accessing relevant information needed online, and thus gain a competitive advantage.

Thanks to the architecture of information, the information space at the enterprise is so organized that it is easy to disseminate information outside the enterprise: to partners, customers, suppliers.

The presented work is the first stage and will be used in the construction of a smart enterprise architecture and the development of a smart enterprise architecture of information.

The basic concepts of the architecture of information of a smart enterprise will be such concepts as knowledge base, knowledge, unstructured information, intelligence, intelligent system, which in its ability to process information potentially exceeds not only human abilities but also the capabilities of the information system of the last generation.

\section{REFERENCES}

1. Meytus V. Yu., Morozova G. I., Kozlova V. P., Taran L. Yu., 2020. "Smart enterprise as a modern form of existence of traditional enterprise in the digital economy", Control Systems and Computers, 1 (285), pp. 23-34. https://doi. org/10.15407/csc.2020.01.023

2. Sizov A., 2010. "Transformatsiya arkhitektury predpriyatiya: prichiny, deystvuyushchiye litsa i puti realizatsii" ["Transformation of enterprise architecture: reasons, actors and ways of implementation"], Direktor informatsionnoy sluzhby [Director of Information Services], 8. [online] Available at: <https://www.osp.ru/cio/2010/08/13003678/> (In Russian).

3. Krasnov S. V., 2012. "Kontseptsiya podderzhki arkhitektury predpriyatiya" ["The concept of supporting the architecture of the enterprise"], Vestnik Volzhskogo universiteta im. V. N. Tatishcheva [Bulletin of the V. N. Tatishchev Volga University], 2 (19), pp. 60-65. (In Russian). 
4. A definition of Enterprise Architecture. [online] Available at: <https://ingenia.wordpress.com/a-definition-of-enterprise-architecture/ $>$ [Accessed 2 May 2021].

5. Umberg E. D. "Arkhitektura informatizatsii kompanii" ["Company informatization architecture"], Center YF. [online] Available at: $<$ https://center-yf.ru/data/Menedzheru/arhitektura-informatizacii-kompanii.php $>$. (In Russian).

6. A definition of IT architecture by Gartner. [online] Available at: <https://www.gartner.com/en/information-technology/glossary/architecture>.

7. Danilin A. V. Elementy arkhitektury predpriyatiya. Biznes-arkhitektura i arkhitektura informatsii [Elements of enterprise architecture. Business architecture and information architecture]. [online] Available at: <https://www.intuit.ru/ studies/coursis/995/152/lecture/4230 page $=8>$. (In Russian).

8. Sessions R. Sravneniye chetyrekh vedushchikh metodologiy postroyeniya arkhitektury predpriyatiya [Comparison of four leading methodologies for building enterprise architecture], ObjectWatch Inc. [online] Available at: <https://microsoft.com/ru-tu/library/11914379.aspx>. (In Russian).

9. Wurman R.S., 1997. Information Architects. Graphics ins., 214 p.

10. Rosenfeld L., Morvile P., 2006. Information architecture for the World Wide Web, 3rd ed., OReily\&Assotiates, 528 p.

11. Korolev O.L., 2011. Metodika otsenki informatsionnogo potentsiala predpriyatiya [Methods for assessing the information potential of the enterprise], Scientific notes of the Vernadsky Tauride National University, series "Economics and Management”, Vol. 24 (63), 1, pp. 109-113. (In Russian).

12. TADVISER. [online] Available at: $<$ https://www.tadviser.ru/index.php/> [Accessed 2 May 2021]

13. Wikipedia. [online] Available at: $<$ https://ru.wikipedia.org/wiki/ $>$ [Accessed 2 May 2021].

Received 28.07.2021

\section{ЛІТЕРАТУРА}

1. Мейтус В. Ю., Морозова Г. І., Козлова В. П., Таран Л. Ю. Smart enterprise as a modern form of existence of traditional enterprise in the digital economy. Control Systems and Computers. 2020. 1 (285). C.23-34. DOI: 10.15407/ csc.2020.01.023.

2. Сизов А. Трансформация архитектуры предприятия: причины, действующие лица и пути реализации. Директор информационной службы. 2010. 8. URL: https://www.osp.ru/cio/2010/08/13003678/.

3. Краснов С. В. Концепция поддержки архитектуры предприятия. Вестник Волжского университета им. В. Н. Татищева. 2 (19). 2012. С. 60-65.

4. A definition of Enterprise Architecture. URL: https://ingenia.wordpress.com/a-definition-of-enterprise-architecture/.

5. Умберг Э. Д. Архитектура информатизации компании. Center YF. URL: https://center-yf.ru/data/Menedzheru/ arhitektura-informatizacii-kompanii.php.

6. A definition of IT architecture by Gartner. URL: https://www.gartner.com/en/information-technology/glossary/ architecture.

7. Данилин А. В. Элементы архитектуры предприятия. Бизнес-архитектура и архи-тектура информации. URL: https://www.intuit.ru/studies/coursis/995/152/lecture/4230 page $=8$.

8. Сешнс Р. Сравнение четырех ведущих методологий построения архитектуры предприятия. Компания ObjectWatch Inc. URL: http://msdn.microsoft.com/ru-ru/library/ee914379.aspx.

9. Wurman R. S. Information Architects. Graphics ins., 1997. 214 p.

10. Rosenfeld L., Morvile P. Information architecture for the World Wide Web. 3rd ed. OReily\&Assotiates, 2006. 528 p.

11. Королев О. Л. Методика оценки информационного потенциала предприятия. Ученые записки Таврического национального университета им. В. И. Вернадского. Серия «Экономика и управление». 2011. Т. 24 (63). 1. С. $109-113$.

12. TADVISER. URL: https://www.tadviser.ru/index.php/.

13. Википедия. URL: https://ru.wikipedia.org/wiki/.

Надійшла 28.07.2021

А.І. Морозова, головний інженер-програміст, 
Міжнародний науково-навчальний центр

інформаційних технологій та систем НАН та МОН України,

просп. Академіка Глушкова, 40, Київ, 03187, Україна,

dep190@irtc.org.ua

В.П. Козлова, науковий співробітник,

Міжнародний науково-навчальний центр

інформаційних технологій та систем НАН та МОН України,

просп. Академіка Глушкова, 40, Київ, 03187, Україна,

dep190@irtc.org.ua

\section{АРХІТЕКТУРА ІНФОРМАЦІЇ СУЧАСНОГО ПІДПРИЕМСТВА В ПЕРІОД ЗАГАЛЬНОЇ ЦИФРОВІЗАЦІЇ ЕКОНОМІКИ}

Вступ. Концепція підприємства реального часу базується на інтеграції всього, що пов’язано з діяльністю підприємства: інфраструктури, систем, інформації, процесів, персоналу. Основою цієї інтеграції є архітектура інформаційних технологій.

Сучасний погляд на інформаційні технології для підприємства показує, що інформаційні технології покликані забезпечити високу ефективність керування підприємством, оптимізувати збирання та накопичення інформації, скоротити терміни прийняття рішень.

Інформаційні технології на сьогодні не тільки забезпечують автоматизацію підприємства, але й перетворюються в елемент його стратегії, необхідний для переходу підприємства на якісно новий рівень функціонування.

Одна з головних проблем підприємства - відсутність коректної інформації про існуючу інформаційнотехнологічну підтримку бізнесу та стратегії його подальшого розвитку. Виникає парадоксальна ситуація інформаційні технології підвищують ефективність керування підприємством, але при цьому їхній розвиток має хаотичний характер. Потрібен інструмент, що забезпечує взаємозв'язок стратегічних цілей і задач підприємства, бізнес-процесів та технологій, що їх підтримують.

Вирішення цієї проблеми полягає в розробці архітектури інформації підприємства в умовах цифровізації виробничого процесу.

Мета статті. В період загальної інформатизації суспільства та надзвичайної важливості інформації, стратегічно необхідної для розвитку підприємства, визначити роль створення якісної архітектури інформації на конкурентоспроможному підприємстві.

Акцентувати увагу на результатах розробки архітектури інформації підприємства.

Методи. Системний підхід, аналіз.

Результати. Запропоновано варіант вирішення проблеми підприємства стосовно коректності інформації про інформаційно-технологічну підтримку бізнесу та стратегії його подальшого розвитку у вигляді розробки та побудови архітектури інформації підприємства, яка забезпечує взаємозв'язок стратегічних цілей та задач підприємства, бізнес-процесів та технологій.

Представлено методику розробки архітектури інформації підприємства.

Висновки. В сучасних умовах інформація набуває такого ж значення для діяльності підприємства, як і фінанси, маркетинг, потенціал, продукція. Це означає, що інформація перетворюється в певний вид виробничих ресурсів та інтегрується зі стратегією бізнесу.

Архітектура інформації підприємства дає цілісне розуміння існуючого бізнес-середовища і використовується для вирішення поточнихактуальнихпроблем бізнесу. Вона забезпечує інфраструктурупідприємства можливостями для проєктування нових бізнес-орієнтованих рішень.

Архітектура інформації допомагає звести до мінімуму ризик на підприємстві та підтримує повноцінне планування будь-яких інформаційно-технологічних проектів.

Ключові слова: архітектура підприємства, архітектура інформації підприємства, інформаційно-технологічна інфраструктура, інформаційно-технологічна архітектура підприємства, стратегія розвитку бізнесу. 